九州大学学術情報リポジトリ

Kyushu University Institutional Repository

\title{
DISCOVERY OF THE BEE GENUS PHAROHYLAEUS MICHENER FROM PAPUA NEW GUINEA, WITH DESCRIPTION OF A NEW SPECIES (HYMENOPTERA, COLLETIDAE)
}

Hirashima, Yoshihiro

Roberts, Hywel

https://doi.org/10.5109/2489

出版情報: ESAKIA. 24，pp.63-66，1986-01-31. Entomological Laboratory，Faculty of Agriculture， Kyushu University

バージョン :

権利関係 : 


\title{
DISCOVERY OF THE BEE GENUS PHAROHYLAEUS MICHENER FROM PAPUA NEW GUINEA, WITH DESCRIPTION OF A NEW SPECIES (HYMENOPTERA, COLLETIDAE) ${ }^{1), 2)}$
}

\author{
Yoshihiro HiRASHima \\ Entomological Laboratory, Faculty of Agriculture, \\ Kyushu University, Fukuoka 812, Japan \\ and \\ HYWEL ROBERTS \\ Forest Research Station, Department of Forests, \\ Bulolo, Papua New Guinea
}

\begin{abstract}
The discovery of Pharohylaeus from Papua New Guinea and that of the female of the genus are reported. Pharohylaeus papuanus, a new species, is described.
\end{abstract}

The bee genus Pharohylaeus Michener is monobasic and its type species, Meroglossa lactifera Cockerell, 1910, an Australian species, has been known by the male only. Thus, it has been known that Pharohylaeus is a rare and poorly known genus of bees since Michener erected this genus in 1965.

This paper reports the discovery of Pharohylaeus from Papua New Guinea, discovery of the female of the genus and describes a new species, Pharohylaeus papuanus, based on two female specimens in the National Forest Insect Collection, Forest Research Station, Bulolo, Papua New Guinea.

Genus Pharohylaeus Michener, 1965

Type species : Meroglossalactifera Cockerell, 1910.

Pharohylaeus shows a close relationship with Hylaeus, Palaeorhiza and Meroglossa. It contains large, robust black species, with a few yellow markings on the head, thorax

1) Supported in part by Grants-in-Aid for Overseas Scientific Survey from the Japan Ministry of Education, Science and Culture, No. 5904108 and No. 60043050 to Kyushu University (Prof. Y. $\mathrm{H}$ irashima).

2) Contribution from the Entomological Laboratory, Faculty of Agriculture, Kyushu University, Fukuoka (Ser. 3, No. 200). 
and legs. The habitus of the head and the feature of yellow markings on the body resemble some of the species of Palaeorhiza.Pharohylaeus is most distinctive in having the 2nd recurrent vein of the fore wings ending beyond the end of the 2nd submarginal cell. In addition, Pharohylaeus is separable from Meroglossa by the absence of spines on the outer apical margin of the hind tibia, and from Palaeorhiza and Hylaeus by the presence of one spine on each outer apical margin of the fore and middle tibiae.

One of the most interesting features of Pharohylaeus is the propodeal enclosure, which is strongly elevated (as high as both the metanotum and scutellum), though the dorsal face of it is flat ; the posterior face of this enclosure is vertical (Fig. 1, A), and the posterior margin of the dorsal face emarginate in the middle, leaving conical projections laterally. In the male of lactiferus, the conical projections (although projecting posteriorly) are rather distinctive, but this was neglected before. Michener (1965) describes the "propodeum without sculpturing, horizontal area short, set off by distinct angle from vertical area, more than half of length of triangle vertical".

Another distinctive feature of Pharohylaeus, which was not mentioned by the original author, is that the suture between the mesepisternum and metepisternum is elevated, and sharply keeled on the lower half. This is more pronounced in the female of papuanus, new species, than in the male of lactiferus. This suture is usually flat in other bees, as far as is known.

Description of genus : Mandibles bidentate, glossa of male short and subtruncate (that of female not examined) ; head similar to some Palaeorhiza; ocelli small ; process of labrum triangularly pointed to apex ; malar space visible (narrow) ; preoccipital carina present (in lactiferus), or absent (in papuanus); pronotum high, thick (or broad), flat dorsally as in some Palaeorhiza:scutellum, metanotum and dorsal face of propodeum even and flat (especially in female) ; propodeal enclosure as stated before ; ridge in front of mesocoxa very conspicuous ; posterior margins of mesepisterna (mesopleura), between mesocoxae, keeled and w-shaped ; suture between mesepisternum and metepisternum elevated and sharply keeled on bower half; smooth space between premesocoxal ridge and the keeled suture flat, or slightly excavated. Wings with stigma slender ; apex of marginal cell bent a little away from wing margin ; second submarginal cell narrowed above, smaller than one-half of first ; basal vein nearly interstitial with vein $c u-v$; first recurrent vein meeting with $\mathrm{r}-\mathrm{m}$; second recurrent vein as stated above ; wings with sparse hairs, largely bare basally. Legs with femora more
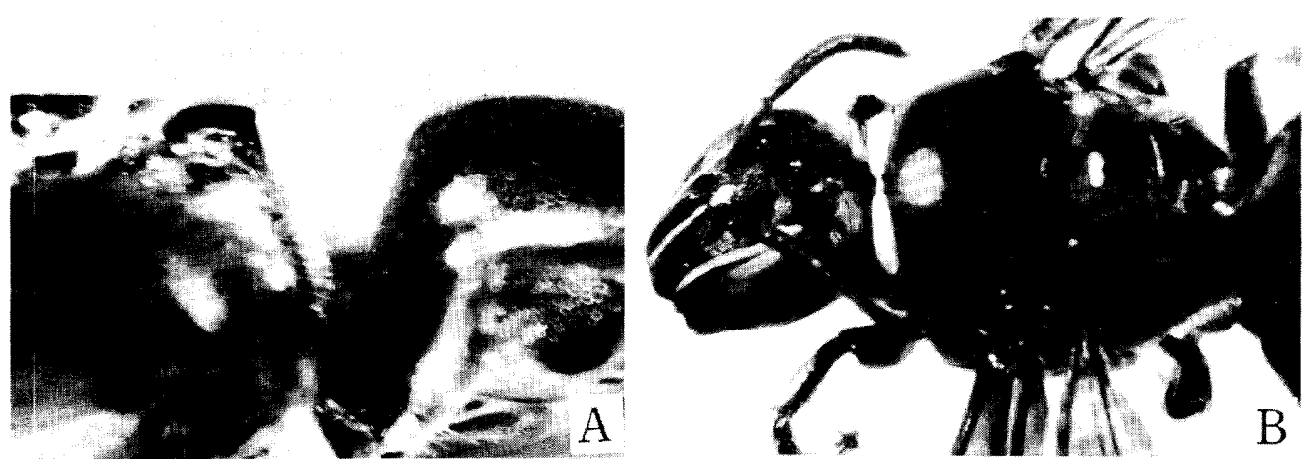

Fig. 1. Holotype female of Pharohylaeus papuanus, new species. A: Posterior part of thorax and basal portion of metasoma, lateral view. B : Head and thorax, dorso-lateral view. 
or less robust ; tibia and tarsus of female fore legs rather short; outer apical margins of fore and middle tibiae each with a short spine ; outer apical margin of hind tibia unarmed ; hind tibial spurs thick, not long, curved near apices. Metasoma with basal three terga very large, others small; basal portion of first tergum convex in the middle as seen from above ; large basal face of 1st tergum nearly vertical (Fig. 1, A) ; second tergum with fovea punctiform ; three basal sterna of male largely exposed; third male sternum with a pair of submedian, preapical lobes, or projections.

Distribution : Australia (Queensland) and Papua New Guinea.

\section{Pharohylaeus papuanus, new species}

Female : Length about $11 \mathrm{~mm}$, fore wing about $8.5 \mathrm{~mm}$ long.

Black, shining, without metallic reflection ; median longitudinal line on clypeus, long slender lines on face along inner margins of eyes, elongate mark on lower portion of supraclypeal area, a basal spot on process of labrum, broad band on pronotum interrupted in the middle, small transverse median mark on the base of scutellum, an evanescent small mark on tegulae and basal spot on fore tibiae ivory. Wings strongly brownish all over, with distinct purple reflection in some light ; veins and stigma fuscous. Tegulae nearly black.

Head more or less small for the size of insect ; inner eye margins converging below except upper portion which converges toward ocelli ; mandibles only slightly narrowed toward apices ; malar space oblique, about, or less than, one-third of basal width of mandible in the middle ; median portion of clypeus broadly *longitudinally depressed; supraclypeal area broad, slightly dilated laterally ; upper portion of supraclypeal area and frons broadly convex with no distinction between them ; ocelli small ; postocellar distance about equal to ocellocular distance, a little less than twice as broad as diameter of posterior ocellus; distance between mid ocellus and posterior ocellus about equal to diameter of the former, which is a little smaller than the posterior one ; vertex convex ; preoccipital carina absent.

Mesoscutum broad, rather flat ; scutellum, metanotum and dorsal face of propodeal enclosure even and flat ; dorsal face of propodeal enclosure about as long as metanotum.

Fore basitarsus about three times as long as broad, much shorter than fore tibia, and slightly longer than next three segments taken together; hind tibia more or less slender, unmodified dorsobasally ; posterior spur of hind tibia finely ciliate, or very finely serrate $(X \mathbf{6 4})$.

Metasoma with 1 st tergum largest, distinctly convex ; 1st tergum with a small, round convexity on the basal portion medially ; 2nd and 3rd terga with sublateral, preapical convexities ; similar convexities obscure on 1st tergum ; 6th tergum without pygidial plate or any other structure.

Clypeus longitudinally lineolate, with sparse, weak, longitudinal punctures ; punctures on vertex and frons irregular, neither strong nor dense; broad longitudinal spaces above antennal sockets glabrous, impunctate; excavated space in front of mid ocellus also smooth, shining, impunctate. Mesoscutum shining, smooth nearly all over (microscopic reticulation visible under $X 64$ ), with weak and very sparse punctures ; scutellum like mesoscutum, with weaker punctures ; metanotum duller than scutellum, with microscopic, more or less close punctures; propodeal enclosure smoother and more shining than metanotum, with microscopic lineolation; propodeum other than enclosure densely punctate or nearly rugose-punctate, dull ; pre- and mesepisterna smooth, very shining, with sparse, piliferous punctures which are stronger than those on mesoscutum; underside of thorax (space between fore- and mesocoxae) also smooth, shining, with coarse (not strong) large punctures; metepisternum dull, with microscopic, dense punctures. Metasoma nearly smooth, shining ; punctures on 1st tergum weak, rather dense (sparse on median portion), those on 2nd more sparse and stronger (especially on lateral portions), those on 3rd considerably larger and much coarser than those on 1st; apical margins of 1 st to 3rd terga broadly impunctate; this impunctate apical margin very broad in the median portion of 1 st tergum.

Hairs on head very sparse ; hairs on thorax also sparse, silvery ; tubercle with marginal fringe 
of dense silver hairs distinctive ; hairs on legs also white except for those on fore tarsi brownish and those on inner faces of hind tarsi slightly ochreous ; hairs on dorsal and outer faces of hind tibia also sparse ; apex of hind tibia with a small tuft of short, white, not dense hairs ; hairs on metasoma also sparse ; 3rd and following terga with blackish hairs; hairs on 6th segment rather dense, nearly black, not especially long on median portions.

Type material: Holotype female, Patep, Logging Area (L. A.), Bulolo, Morobe Province, Papua New Guinea, on flowers of Syzygium aqueum, 2. xi. 1982 (H. Roberts). Paratype female, same data as holotype except it was taken-on 1. xi. 1982.

TyPE DEPOSITORY : British Museum (Nat. Hist.), London.

Distribution : Papua New Guinea.

Diagnosis : Unfortunately, this new species is known by the female only. It is easely separated from Pharohylaeus lactiferus, an Australian species, which is known only by the male, by the absence of any preoccipital carina. Pharohylaeus papuanus is also distinctive in having the wings much darker, and the punctation on the mesoscutum and mesepisternum much sparser than in lactiferus.

\section{Acknowledgements}

We are grateful to Prof. C. D. Michener, Department of Entomology, University of Kansas, U. S. A. for the loan of a male of Meroglossa lactifera Cockerell, which was made in 1977 to Hirashima. Without this specimen the correct assignment of the Papuan female to Pharohylaeus could not be made.

\section{R eference}

Michener, C. D., 1965. A classification of the bees of the Australian and south Pacific Regions. Bull. Amer. Mus. Nat. Hist., $130:$ l-362, 15 pls. 